\title{
16. 中心静脈圧の新しい測定方法の検討
}

中心静脈圧は右心房内压学含み, それに連続 する胸腔内上下大静脈管内圧であり，これまで 測定等の問題もあって，その圧波形の変化よ り, 臨床的にはむしろその充满压や平均圧とし ての変化のみが検討されてきた。しかしながら 中心静脈圧はその圧波形を正確に㹡大記録する ことができれば，拍動流下の循環系の中で高圧 系と低圧系との接点である右心房を含む低圧系 の内圧変化として捉えられ，循環生理学的にも 新しい観点からその臨床的意義の発展を認める ことができるものと考え，新しい右心房圧昖大 記録用増幅装置を考案し検討した。

\section{装置および研究方法}

ミラーカテ先トランスジューサを用いて右心 房压を測定し，新しく考案したオフセット電圧 補償回路を通して，常に記録幅内に十分桩大し たa 波並びに $\mathrm{c}$ 波等の波形を経時的に測定記録 寸ることができた。そこで同様の回路を用いて 得られた抬大 $\mathrm{p}$ 波とともに, 脱血並びに還血操 作, VCI 遮断, 高位脊麻時低血圧, それ詨 する Volume therapy,さらに inotropic effect を有する昇圧剤の効果等による変化を開胸犬を 用いて追求した。

図 1一(1) 快直結形心電計 のブロック図で, Sample hold 回路はR波から任意の時間後に心 電図@を Sample hold し，そのときのオフセ ット電圧と絶対值が等しく逆極性の電圧(bを作 り，これを@に加算することによりオフセット 電圧を除去して出力信号(C)を基線レベルに戻 す. 又 Sample hold 回路が hold mode の場 合, この回路全体は単なる直流増幅回路として

* 久留米大学医学部麻醉科
無敵剛介*高木俊明*徳安みどり* 堤 宜敬*津田英照*能美 博*

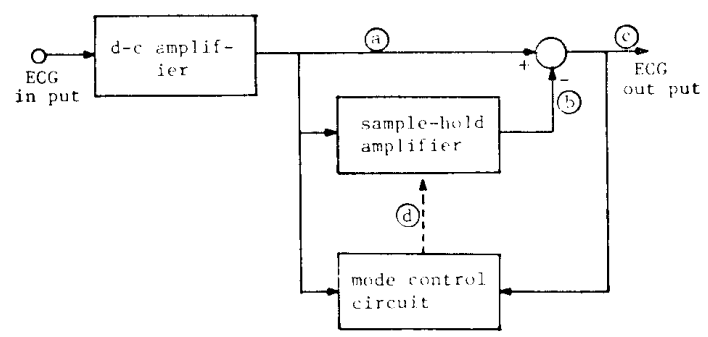

図 1-(1) Block diagram of direct coupled electrocardiograph

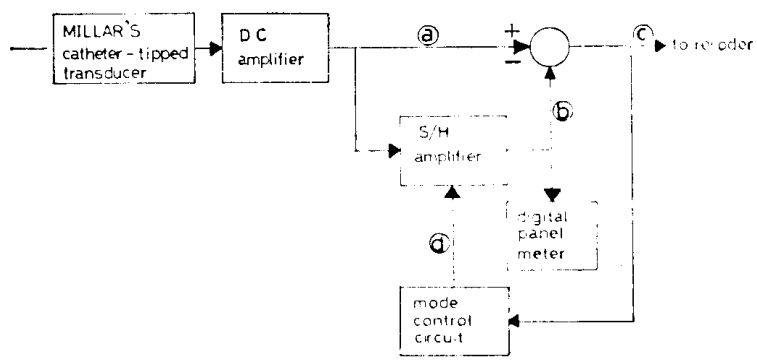

図 1 --(2) 右心房王拡大記録用增幅回路

動作方るので波形の忠実度は全く理想的なもの となる。このことは， $\mathrm{p}$ 波等の低周波成分を定 量化する上で特に重要と思われる。

右心房圧拡大記録用増幅回路も同様であり， 図 1 一(2) 亿示す. Sample hold 回路は設定值を 越えた場合にそのときの右心房圧@を Sample holdし，これを絶対值が等しく逆極性電圧(を つくり，これに@を加算することにより出力信 号〔を基線レベルに戻す. 基線レベルの変動值 は digital panel meterで表示される。

\section{研究結果}

図 2 に示寸如く，一定量の脱血をくる返寸こ とにより, 右心房圧が次第に下降し, ついに記 録幅の下限界を越して波形全体をとらえること ができなくなった際，自動的に記録幅中央に基 線レベルが移動し, 全波形を記録幅内に描かせ 


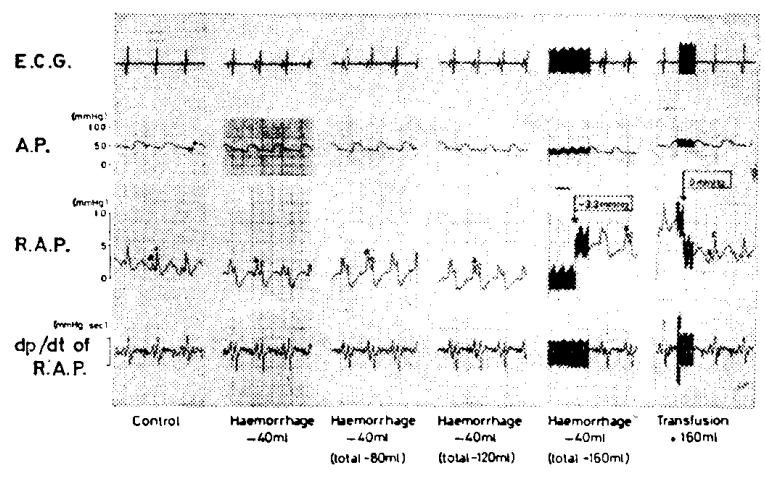

图 2 Continuous Recording of Right Atrial Pressure and $\mathrm{dp} / \mathrm{dt}$ of $R$. A. P. on Haemorrhage and Transfusion

Dog 우 $8 \mathrm{~kg} 1978.4 .11$

その変動値は digital panel meter に明示させ る.さらに還血により今度は記録幅の上限を越 えた際も同じ基線レベルが中央に移動する。こ れにより種々の条件下で右心房圧 $\mathrm{a}$ 波, $\mathrm{c}$ 波等 の波形の変化及びその压を正確に捉えることが できた。

図 3 は上段より E. C. G.，大動脈圧，抎大記 録装置を用いた搪大 $\mathrm{p}$ 波，抬大右心房圧，その 一次微分波形, 大動脈起始部血流量を示寸. 春 麻後, 右心房圧は低下寸ると同時に $\mathrm{a}$ 波が $\mathrm{c}$ 波 より著明に低下しているのが認められる，一方 輸液により血圧を回復せしめると， $\mathrm{a}$ 波，c 波 共に回復している状況がよく観察できる.

ついで a 波 $\mathrm{dp} / \mathrm{dt}$ 最大值と stroke volume

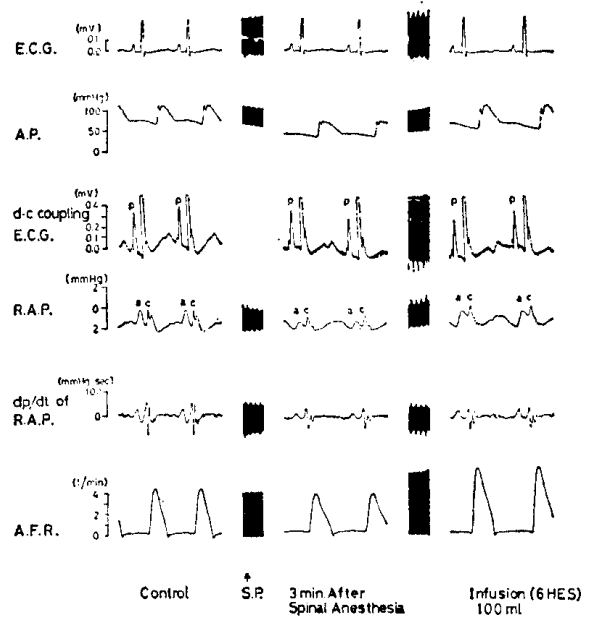

图 3 Original Recording of Hemodynamic Parameters due to High Spinal Anesthesia and Infusion

Dog 우 $10 \mathrm{~kg}$
との関係（図 4 ）及び c 波 $\mathrm{dp} / \mathrm{dt}$ 最大值と stroke volume との関係（図 5 ) を各種循環動 態下において検討してみた。縦軸にそれぞれa 波 $\mathrm{dp} / \mathrm{dt}$ 最大值, $\mathrm{c}$ 波 $\mathrm{dp} / \mathrm{dt}$ 最大值, 横軸に stroke volume をそれぞれコントロール值から の\%で表示し，コントロールを中心として四象 限に変化方向を分けてみると, 両者とも增加す る第 1 象限への変化は脱血後の還血, 輸液, 並 びに标麻時低血圧に対する輸液後の Dobutamine の投与の場合であり，両者が減少する第 3 象限への変化方向を示寸ものは高位脊麻, VCI 遮断, フローセン麻酔, 出血等による血圧低下 時であった。

拡大 $\mathrm{p}$ 波のたちあがりから $\mathrm{a}$ 波 $\mathrm{dp} / \mathrm{dt}$ 最大值

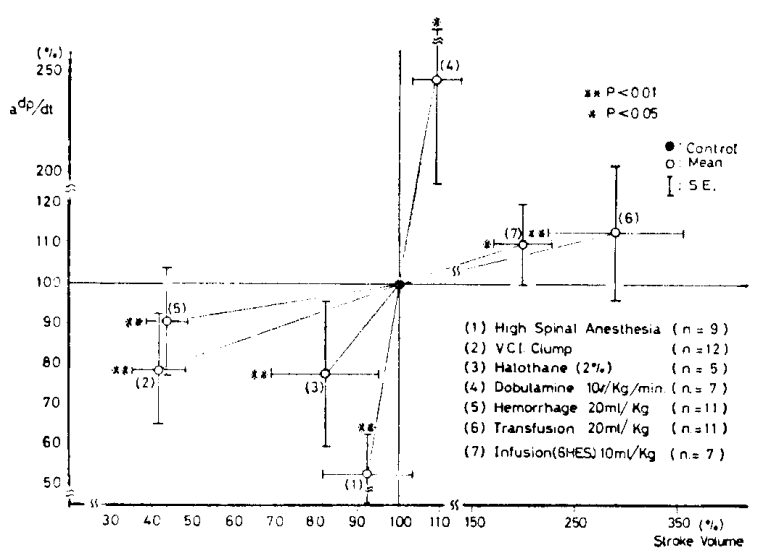

図 4 Director of Changes of Relationship between $\mathbf{a}_{\mathrm{dp}} / \mathrm{dt}$ of R.A.P. and Stroke Volume under Various Hemodynamic Changes

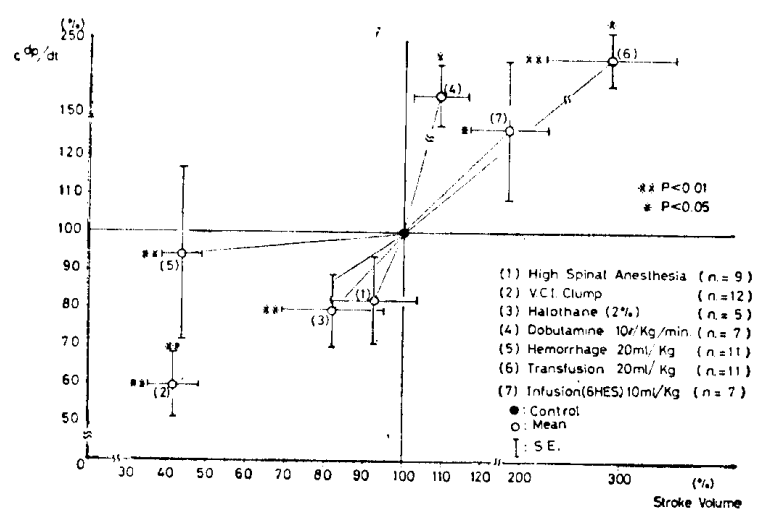

因 5 Director of Changes of Relationship between $c_{d p} / d t$ of R.A.P. and Stroke Volume under Various Hemodynamic Changes 
までの時間は，右心房が電気的に興奮し機械的 に収縮するまでの時間に相当し，心電図 $R-R$ 間隔に対する百分率で表わし，これを右心房の electromechanical time ratio とし, 経時的に 追求すると図 6 の如く，八ローセン麻酔時に有 意に増加した。 心電図 $\mathrm{p}$ 波より右心房圧 $\mathrm{c}$ 波 $\mathrm{dp} / \mathrm{dt}$ 最大值までの時間は, 同じく右心室の収 縮運動による三尖弁の右心房内膨隆 までの時 閒，つまり右心房の受動的充溢期を含み，その reseroir fumction の時間的指標と考えられる。 Stroke volume とその関連をみると，高位脊麻 時低血圧に扔いて有意の低下を認めた。

\section{考案ならびに結語}

（1）右心房圧波の拡大記録の際，通常記録幅 を逸脱する波形を Sample hold 回路を利用し て正確に捉えることができた，同様の方法で， 心電図拡大 $\mathrm{p}$ 波も同時記録できた。な扔，大力 部には Burr-Brown の光結合 Isolation-Amp. を用い安全性を高めた。

(2) $\mathrm{a}_{\mathrm{dp}} / \mathrm{dt}$ 波最大值は, 右心房の booster pump の機能と関連し， p 波より a 波 $\mathrm{dp} / \mathrm{dt}$ 最 大值までの時間は右心房が電気的に興 奮し， dynamicな働きを開始するまでの時間であり， 右心房の electromechanical time として経時 的に追求できた. 各種循環動態下に Stroke

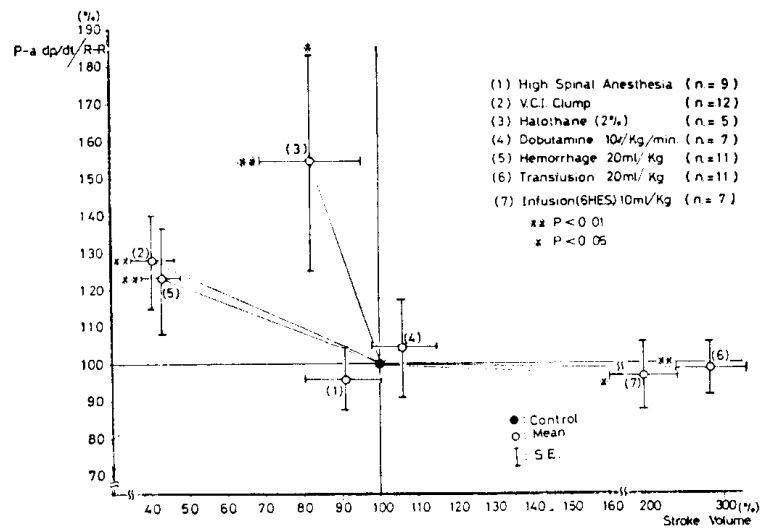

图 6 Electromechanical Time Ratio of Right Atrium

volume との関連をみると, 各種条件下で変化 方向が異なるのを認めた。

(3) $\mathrm{p}$ 波より $\mathrm{c}$ 波 $\mathrm{dp} / \mathrm{dt}$ 最大值は同じく右心 室の収縮翼動による三尖弁の右心房内膨隆まで の時間, つまり右心房の受動的充溢期を含み, そのResevoir function の時間的指標と考えら れ, Stroke volume との関連において経時的に 追求できた。

（4）右心房圧拡大記録の実現により，各波形 の変化を経時的に捉えることができ，従来の中 心静脈圧の臨床的意義を更に拉大発展させる可 能性があるものと考える。 